\title{
Correction to: Insights into the mechanism(s) of digestion of crystalline cellulose by plant class C GH9 endoglucanases
}

\section{Siddhartha Kundu ${ }^{1}$}

Published online: 27 July 2020

(C) The Author(s) 2020

Correction to: Journal of Molecular Modeling (2019) 25: 240 https://doi.org/10.1007/s00894-019-4133-1

The article Insights into the mechanism(s) of digestion of crystalline cellulose by plant class C GH9 endoglucanases, written by Siddhartha Kundu, was originally published Online First without Open Access. After publication in volume 25, issue 8 , article number 240 the author decided to opt for Open Choice and to make the article an Open Access publication. Therefore, the copyright of the article has been changed to (c) The Author(s) 2020 and the article is forthwith distributed under the terms of the Creative Commons Attribution 4.0 International License (http://creativecom mons.org/licenses/by/4.0/), which permits use, duplication, adaptation, distribution and reproduction in any medium or format, as long as you give appropriate credit to the original author(s) and the source, provide a link to the Creative Commons license, and indicate if changes were made.
Open Access This article is licensed under a Creative Commons Attribution 4.0 International License, which permits use, sharing, adaptation, distribution and reproduction in any medium or format, as long as you give appropriate credit to the original author(s) and the source, provide a link to the Creative Commons licence, and indicate if changes were made. The images or other third party material in this article are included in the article's Creative Commons licence, unless indicated otherwise in a credit line to the material. If material is not included in the article's Creative Commons licence and your intended use is not permitted by statutory regulation or exceeds the permitted use, you will need to obtain permission directly from the copyright holder. To view a copy of this licence, visit http://creativecommons.org/licenses/by/4.0/.

Publisher's note Springer Nature remains neutral with regard to jurisdictional claims in published maps and institutional affiliations.

The online version of the original article can be found at https://doi.org/ 10.1007/s00894-019-4133-1

Siddhartha Kundu

siddhartha_kundu@yahoo.co.in

1 Department of Biochemistry, Army College of Medical Sciences, Brar Square, Delhi Cantt, New Delhi 110010, India 